\title{
The Czech Agrarian Foreign Trade Comparative Advantages
}

\author{
Luboš SMUTKA, Michal STEININGER \\ Czech University of Life Sciences Prague, Prague, Czech Republic \\ \{smutka, steininger\}@pef.czu.cz
}

\begin{abstract}
The character of Czech agrarian trade activities was changed in the $21^{\text {st }}$ century. The Czech agrarian trade became even more focused on developed and especially European union countries agri-food markets. The aim of this paper is to identify the main changes affecting territorial and commodity structure within the period 2001 and 2015. Paper is focused especially on Czech agri-food trade volume, value, unit price and competitiveness analyses. Individual analyses are specified in relation to EU28, non-EU countries, World and OECD vs. Developing countries. - In relation to all analyzed group of countries, the Czech value of Czech agrarian exports and imports recorded the significant growth. The positive figure of Czech agri-food trade activities is much faster inter-annual growth rate of exports in relation to the value of imports. Czech agri-food trade balance is stabilized and import/export covering ration is recorded the positive changes. The weakness of Czech agri-food trade activities is low unit price of Czech exports in comparison to imports unit prices. Competitiveness of Czech agri-food trade is especially pushed through the growth of exported volumes. The added value in Czech agri-food trade value growth is very limited. The number of Czech agri-food trade competitive items is increasing (but they have very limited added value).
\end{abstract}

Keywords: Territorial and Commodity Structure, Agri-Food Trade, Comparative Advantage.

\section{Introduction}

This article analyses the basic transformation trends related to Czech agrarian foreign trade territorial and commodity structure in the period of 2001 to 2015.

Commodity structure in particular recorded significant changes during the analysed period $(2001-2015)$. Finalized and especially semi-finalized food products increased their share both in export and also import activities [13]. The mentioned trend is related to two factors: the growth of economic power and also the restructuralization of the Czech foodstuff market [2]. Territorial structure has become more specifically concentrated on EU countries [1]. The importance of so called non-European and especially the "third" countries is diminishing [3]. The last really significant non-EU partner Russian federation is constantly reducing its share in Czech agrarian trade. 
The importance of Russia is reduced because of political consequences [15] and because of Russian market specifics $[9,10]$.

Czech agrarian trade represents an extremely specific part of Czech economy performance [1]. The character of agrarian trade was affected by the transformation process from command/central planned economy to market economy. It was also affected by the reduction of agricultural production performance and the government effort to encourage cooperation especially in relation to other European countries [16].

Very important event for the Czech agrarian market was the EU accession. Even before that event, the Czech Republic was preparing itself for membership and the necessity to eliminate almost all barriers protecting Czech agrarian market both in relation to "old" EU and "new" EU members [4]. The transformation process especially in the period before Czech accession was not really a positive one [14]. The Czech Republic, as with other Central European countries, reduced the importance of non-EU territories and began focusing its trade activities specifically on European partners $[7,8,12]$.

The period immediately after the accession significantly encouraged not only the export, but also import performance [17]. During the first years of Czech EU membership the import value was growing even faster in comparison to export value development. The result was a constantly growing negative trade balance performance until 2011 (the record negative trade balance was reached at about 36 billion CZK).

The current Czech agrarian trade is standing at very important crossroad. In relation to future possible liberalization processes (e.g. TTIP, CETA, Doha Development Agenda etc.) can be expected more significant changes affecting the future agrarian value, volume and structure.

\section{Data and methods}

This paper aims to identify changes which have occurred during the analysed time period from 2001 to 2015. This paper is focused specifically on the period of Czech EU membership. Territorial structure is analysed both in relation to the EU countries and also in relation to the "third countries" (e.g. OECD, World without the EU, Developing countries). The Commodity structure is analysed especially in relation to added value development and distribution. We applied HS system: HSO1 Live animals, HS02 Meat and edible meat offal, HS03 Fish and crustaceans, molluscs and other aquatic invertebrates, HS04 Dairy produce birds' eggs natural honey edible products of animal origin, not elsewhere specified or included, HS05 Products of animal origin, not elsewhere specified or included, HS06 Live trees and other plants bulbs, roots and the like cut flowers and ornamental foliage, HS07 Edible vegetables and certain roots and tubers, HS08 Edible fruit and nuts peel of citrus fruit or melons, HS09 Coffee, tea, mate and spices, HS10 Cereals, HS11 Products of the milling industry malt starches inulin wheat gluten, HS12 Oil seeds and oleaginous fruits miscellaneous grains, seeds and fruit industrial or medicinal plants and fodder, HS13 
Lac gums, resins and other vegetable saps and extracts, HS14 Vegetable plaiting materials vegetable products not elsewhere specified or included, HS15 Animal or vegetable fats and oils and their cleavage products prepared edible fats animal or vegetable waxes, HS16 Preparations of meat, of fish or of crustaceans, molluscs or other aquatic invertebrates, HS17 Sugars and sugar confectionery, HS18 Cocoa and cocoa preparations, HS19 Preparations of cereals, flour, starch or milk pastrycooks' products, HS20 Preparations of vegetables, fruit, nuts or other parts of plants, HS21 Miscellaneous edible preparations, HS22 Beverages, spirits and vinegar, HS23 Residues and waste from the food industries prepared animal fodder, HS24 Tobacco and manufactured tobacco substitutes.

The paper also specifies the distribution of comparative advantages both in relation to EU single market and also in relation to the rest of the world. To reach the above, mentioned objectives, the paper applies the basic and competitiveness analyses (Lafay index and trade balance index). The results coming from individual analyses are highlighted through the modified "Product mapping method", identifying the process of Czech agrarian foreign trade commodity structure profiling. Data sources are following: UN COMTRADE, Czech statistical office.

$$
L F I_{j}^{i}=100\left(\frac{x_{j}^{i}-m_{j}^{i}}{x_{j}^{i}+m_{j}^{i}}-\frac{\sum_{j=1}^{N}\left(x_{j}^{i}-m_{j}^{i}\right)}{\sum_{j=1}^{N} x_{j}^{i}+m_{j}^{i}}\right) \frac{x_{j}^{i}+m_{j}^{i}}{\sum_{l=1}^{N} x_{j}^{i}+m_{j}^{i}}
$$

For a given country $i$, and for any given product $j$, the Lafay index [11] is defined by the formula (1) above, where $x_{j}^{i}$ and $m_{j}^{i}$ are exports and imports of product $j$ of country $i$, towards and from the particular region or the rest of the world, respectively, and $N$ is the number of items.

Positive values of the Lafay index indicate the existence of comparative advantages in a given item; the larger the value the higher the degree of specialization [19].

Trade Balance Index is simply formulated as follows:

$$
T B I_{j}^{i}=\frac{x_{j}^{i}-m_{j}^{i}}{x_{j}^{i}+m_{j}^{i}}
$$

where $\mathrm{TBI}_{\mathrm{j}}^{\mathrm{i}}$ denotes trade balance index of country $i$ for product $j ; x_{j}^{i}$ and $m_{j}^{i}$ represent exports and imports of group of products $j$ by country $i$, respectively [11].

A country is referred to as a "net-importer" in a specific group of products if the value of TBI is negative, and as a "net-exporter" if the value of TBI is positive [18].

The next part of the analysis presented in this paper was conducted using the "products mapping", which enables the user to assess leading exported products from two different points of view, i.e. domestic trade-balance and international competitiveness. [18] The figure 1 represents a matrix for the distribution of the entire set of exported products into 4 groups according to the two selected indicators: 


\begin{tabular}{|c|c|c|}
\hline 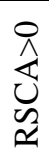 & $\begin{array}{c}\text { Group B: } \\
\text { Comparative Advantage } \\
\text { Net-importer } \\
(\text { RSCA }>0 \text { and } \mathrm{TBI}<0)\end{array}$ & $\begin{array}{c}\text { Group A: } \\
\text { Comparative Advantage } \\
\text { Net-exporter } \\
(\text { RSCA }>0 \text { and } \mathrm{TBI}>0)\end{array}$ \\
\hline \multirow[t]{2}{*}{ 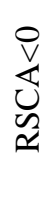 } & $\begin{array}{c}\text { Group D: } \\
\text { Comparative disadvantage } \\
\text { Net-importer } \\
(\text { RSCA }<0 \text { and } \mathrm{TBI}<0)\end{array}$ & $\begin{array}{c}\text { Group C: } \\
\text { Comparative disadvantage } \\
\text { Net-exporter } \\
(\text { RSCA }<0 \text { and } \mathrm{TBI}>0)\end{array}$ \\
\hline & TBI $<0$ & TBI $>0$ \\
\hline
\end{tabular}

Fig. 1. Product mapping scheme. [18]

The Revealed Symmetric Comparative Advantage (RSCA) is the indicator of comparative advantage (The values of $\operatorname{RSCA}_{\mathrm{j}}^{\mathrm{i}}$ index can vary from minus one to one. $\operatorname{RSCA}_{\mathrm{j}}^{\mathrm{i}}$ greater than zero implies that country $i$ has comparative advantage in a group of products $j$.) [6] and TBI is the indicator of export-import activities [11]. RSCA index is formulated as follows:

$$
R S C A=\frac{R C A_{j}^{i}-1}{R C A_{j}^{i}+1}
$$

Because the original approach does not take into consideration the real intensity/influence of imports, we decided to modify the original "product mapping approach".

\begin{tabular}{|c|c|c|c|}
\hline \multirow{2}{*}{ 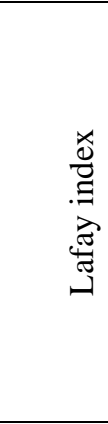 } & $\underset{\underset{I}{\Delta}}{\stackrel{0}{\Lambda}}$ & $\begin{array}{c}\text { Group B: } \\
\text { Comparative } \\
\text { Advantage } \\
\text { Net-importer } \\
(\mathrm{LFI}>0 \text { and } \mathrm{TBI}<0) \\
\end{array}$ & $\begin{array}{c}\text { Group A: } \\
\text { Comparative Advantage } \\
\text { Net-exporter } \\
(\mathrm{LFI}>0 \text { and } \mathrm{TBI}>0)\end{array}$ \\
\hline & $\frac{\stackrel{\vartheta}{V}}{\stackrel{I}{a}}$ & $\begin{array}{c}\text { Group D: } \\
\text { Comparative } \\
\text { disadvantage } \\
\text { Net-importer } \\
(\mathrm{LFI}<0 \text { and } \mathrm{TBI}<0) \\
\end{array}$ & $\begin{array}{c}\text { Group C: } \\
\text { Comparative } \\
\text { disadvantage } \\
\text { Net-exporter } \\
(\text { LFI }<0 \text { and } \mathrm{TBI}>0) \\
\end{array}$ \\
\hline \multirow{2}{*}{\multicolumn{2}{|c|}{$\begin{array}{c}\text { Czech Agrarian Foreign Trade } \\
\text { Commodity Structure }\end{array}$}} & TBI $<0$ & TBI $>0$ \\
\hline & & \multicolumn{2}{|c|}{ Trade Balance Index } \\
\hline
\end{tabular}

Fig. 2. Modified product mapping scheme.

Figure 2 represents the modified matrix for the distribution of the entire set of exported products into 4 groups according to the two selected indicators. 


\section{Results and discussion}

The Czech agrarian sector still does not finish the process of its restructuring and its commodity structure profile is constantly changing. The EU share in the Czech agricultural trade reaches about $90 \%$ in the long-term. The Czech agricultural exports and also imports are based on a relatively small number of commodity aggregations. Czech exports are able to compensate for even the growth of imports - especially through its increasing added value. The key aspect of the Czech agrarian trade is its competitiveness.

Czech agrarian trade is heavily focused on European territory. There is the significant growth of export and import value performance in relation to all main territories representing the main Czech agrarian trade partners, if we compare the period between 2001 and 2015. For details see table 1:

Table 1. Czech agrarian foreign trade value development in 2001 and 2015 in ths. CZK. [5]

\begin{tabular}{|c|c|c|c|c|c|}
\hline 2001 & EU28 & OECD & World without EU28 & $\begin{array}{c}\text { Developing } \\
\text { economies }\end{array}$ & World total \\
\hline Export & 41116307 & 39951650 & 8295196 & 9459853 & 49411503 \\
\hline Import & 51181539 & 55267004 & 18043402 & 13957937 & 69224941 \\
\hline 2015 & EU28 & OECD & World without EU28 & $\begin{array}{c}\text { Developing } \\
\text { economics }\end{array}$ & World total \\
\hline Export & 185235908 & 181291061 & 16831159 & 20776006 & 202067067 \\
\hline Import & 188674925 & 195918421 & 32536791 & 25293295 & 221211716 \\
\hline
\end{tabular}

The Czech agrarian export growth rate exceeded the import growth rate especially in relation to the EU28, OECD members and non-European countries. The only regions increasing their imports to the Czech Republic faster than the Czech Republic exported to them are European countries without the EU and CIS members.

The Czech Republic reduced its negative trade balance share both in relation to total agrarian trade turnover and export value. The situation improved especially in relation to the EU28, other European countries and OECD members. Czech agrarian trade became extremely concentrated during the last 15 years. All indices proved the existence of Czech agrarian trade comparative disadvantages both in relation to the EU28 and also in relation to the third countries. Czech agrarian trade is probably able to be competitive, especially because of its constantly improving trade performance. The existence of comparative advantages is proved through the application of LFI and RSCA indices taking into consideration only agricultural trade performance. The below mentioned figure 3, provides an overview related to individual Czech agrarian trade items competitiveness: The first two graphs (1 and 2) provide an overview utilizing a classical product mapping approach and the other graphs (3 and 4) provide a different overview through the modified product mapping approach. 


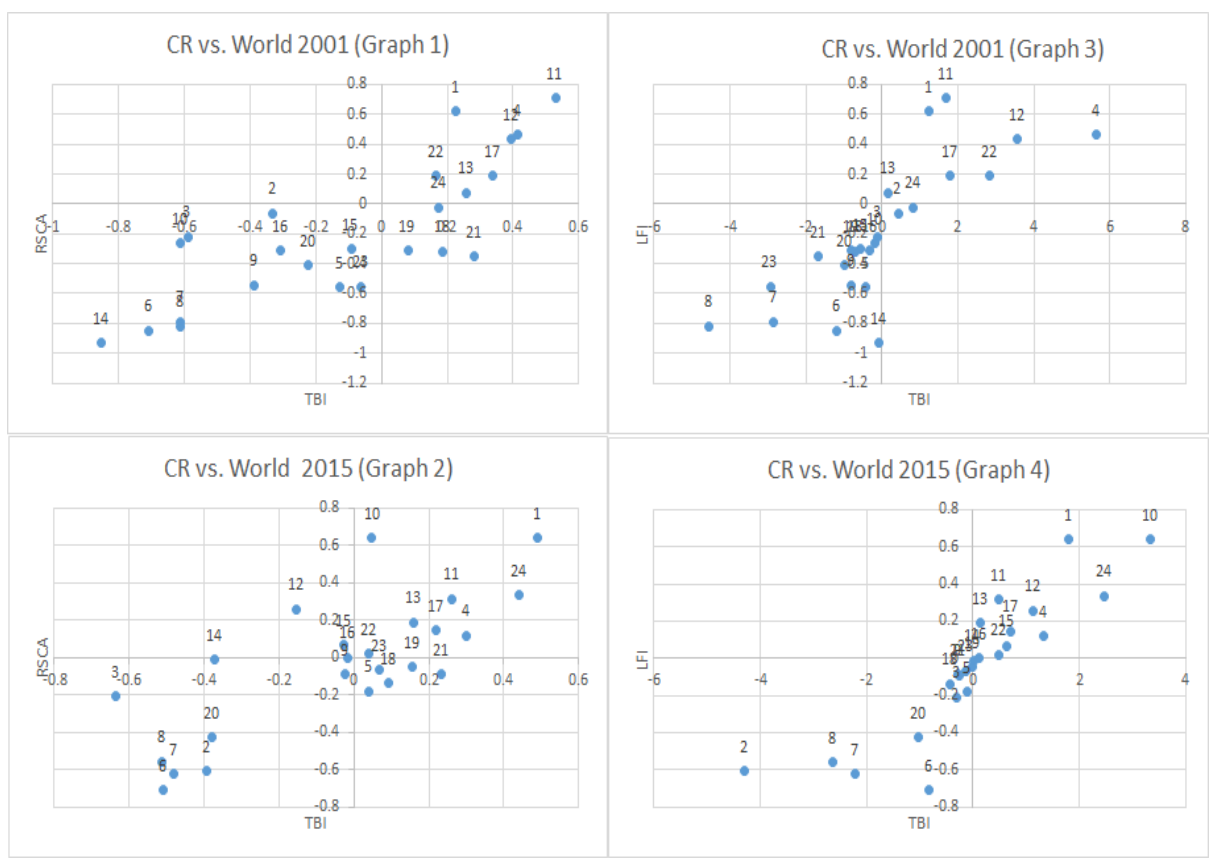

Fig. 3. Czech agrarian exports' comparative advantages distribution - traditional and modified "Product mapping approach".

The number of items located in groups $\mathrm{B}$ and $\mathrm{C}$ are significantly reduced. The whole commodity structure is divided into two groups A (having comparative advantages) and $\mathrm{D}$ (without comparative advantages). The modified approach is able to specify in more detail, the current level of Czech agrarian trade competitiveness and competitiveness development.

It is evident that the Czech agrarian trade commodity structure has been significantly changing its character. The commodity structure is still looking for its optimal state. Comparative advantages are especially influenced by bilateral relations. The Czech Republic is not competitive at a general level, but it is able to get comparative advantages at least at the bilateral level especially because of its EU membership and also because of the existence of special agreements between the EU and selected partners. Czech territorial structure is becoming more and more concentrated - even the share of developing countries in our trade performance is consistently decreasing because of re-exports from other European countries and our export profile is becoming more and more concentrated. The specialization process is negatively affecting some traditional production sectors (e.g. pork meat, fruit, etc.) and it is also reducing Czech food self-sufficiency.

The above mentioned calculations do not take in consideration the significant differences existing among individual regions or groups of countries in relation to their agrarian trade activities. Some countries have been applying very strict trade policy and some countries are very liberal. The Czech Republic as an EU member can operate within the EU market without any restriction. In relation to some territories as 
e.g. CIS, Czech agrarian trade is influenced by multilateral agreements signed under the WTO and also signed at the bilateral level between individual CIS members and the EU. If we want to understand the real comparative advantages distribution, it is necessary to analyse them in relation to several groups of countries (EU28, European countries without the EU and CIS members, CIS members, OECD members, world without the EU28, CIS and OECD countries).

The significant dynamics of commodity structure development can be seen both in relation to the LFI and the TBI index. The significant changes in Czech agrarian trade competitiveness between 2001 and 2015 can be seen especially in relation to EU28 and other European countries. The share of A group products in total agrarian exports significantly increased between the years 2001 and 2015. The share of items located in group D has significantly reduced. Developing countries did not change their role in Czech agrarian export and import activities according to TBI and LFI values distribution.

The majority of Czech agrarian trade value is realized on the base of a proved comparative advantage in relation to individual groups of partners (almost 58\% of total exports). The significant part of exports is realized under the group D. Those exports do not have comparative advantages (cc $40 \%$ of total agrarian exports). This trend can be explained through a deeper territorial structure analyses and also through traded products added value and unit prices. Deeper territorial structure analyses realized country by country is able to specifically identify the Czech agrarian trade competitiveness in relation to individual trade partners. The analysis based on the whole set of countries is only able to identify the prevalence of trends, but it does not provide an exact overview for every single partner. The other reason of our competitiveness is a much lower unit price (2015) of Czech exports (average value of export unit price reached $10.3 \mathrm{CZK} / \mathrm{kg}$ ) in comparison to imports (average value of import unit price reached $28.5 \mathrm{CZK} / \mathrm{kg}$ ). In 2001 the average export respectively import unit price reached $16 \mathrm{CZK} / \mathrm{kg}$ respectively $22 \mathrm{CZK} / \mathrm{kg}$. The competitiveness of Czech exports is based on constantly decreasing unit price value and export price/import price unit ratio. Another important stimuli supporting Czech agrarian trade, especially during the last couple of years, is the significant effort of the Czech central bank to keep the exchange rate at a low level (cc $27 \mathrm{CZK/EUR).}$

The majority of Czech agrarian trade activities is realized in relation to Developed countries. The specific role within that group of countries is kept by EU28 members. Czech agrarian exports and imports increased during the analysed time by $353 \%$ respectively $254 \%$. Commodity structure of Czech agrarian trade recorded significant changes during the analysed time period. Group A increased from cc $40 \%$ to cc $48 \%$, Group B and C experienced only a fractional change (from $6.6 \%$ to $5.6 \%$ ) and the share of group D in total agrarian trade performance was reduced from cc 54\% to $47 \%$.

EU28 are the main trade partners of the Czech Republic (their share in total Czech agrarian trade within the analysed time period was cc $78 \%$ respectively $88 \%$ ). The value of exports and imports increased by cc $350 \%$ respectively cc $268 \%$. The share of Group A transactions in total agrarian trade increased from $38.55 \%$ to $55.21 \%$. The share of Groups B and C was reduced from cc $4.74 \%$ to $0 \%$. And the share of Group 
D was reduced from $56.7 \%$ to $44.8 \%$. The Czech exports to the EU28 became, during the analysed period, more focused on competitive items.

Developing countries represent only a minor share of Czech agrarian trade - cc $11 \%$. The share of those countries was significantly reduced (in 2001 it was cc 20\%). Czech agrarian exports and imports realized in relation to developing countries, significant growth by cc $120 \%$ respectively cc $80 \%$. The growth rate was significantly lower in comparison to OECD respectively EU28 members. The share of Group A increased from $36 \%$ to $49 \%$, the share of Groups B and C is extremely low at only cc $2.2 \%$ and the share of Group D recorded a significant reduction from $64 \%$ to $49 \%$.

\section{Conclusion}

Development has affected the level of Czech agrarian trade concentration during the last fifteen years. The commodity structure has become more diversified, while the territorial structure has become even more concentrated. While in 2001 the share of TOP5 and TOP10 commodity items in total agrarian exports reached 52\% respectively $76 \%$, in 2015 it was $41 \%$ respectively $70 \%$. The Czech trade is quite competitive, especially in relation to the European countries (EU28, CIS and the rest of Europe). The competitiveness in relation to other territories (especially developing countries and not European OECD members) is limited.

The modified product mapping approach proved that the process of Czech agrarian trade restructuralization in relation to traditional partners (especially the Europeans) is still running and it is close to its final state. The trade profile is still developing in relation to other partners and we are very far from the final state of commodity structure. There are still too many items exported under group D. The significant weakness of the Czech agrarian trade is its ability to generate added value. While the value of Czech agrarian exports and imports increased 4.1 times respectively 3.2 times, the volume of Czech agrarian trade especially exports increased more than 6.35 times. The export volume is growing much faster in comparison to import volume (2.5 times). During the monitored time period (2001 - 2015), the volume of Czech exports increased by 16.5 million tonnes, while the import volume increased by 4.6 million tonnes. The result was the significant disproportion between the Czech agrarian trade export and import unit price. While in 2001 the export and import unit prices reached 16.01 CZK/kg respectively $22.25 \mathrm{CZK} / \mathrm{kg}$, in 2015 it was about 10.31 $\mathrm{CZK} / \mathrm{kg}$ respectively $28.55 \mathrm{CZK} / \mathrm{kg}$. The negative results are influenced by the high portion of unprocessed water and wheat in Czech agrarian export. The Czech agrarian exports realized under the group A are suffering because of constantly increasing imports. While the share in 2001 under the group A realised only 17\% of total imports in 2015 , it was already cc $33 \%$. The share of export values realized under the group A within the same period increased only from cc $52.5 \%$ to $57.5 \%$.

The TBI and LFI analyses combination proved the existence of comparative advantages in relation to the following set of aggregations: Cereals, Live animals, Oil seeds, Tobacco products, Dairy products, Sugar, Vegetable oils, saps and plaiting materials, Milling products, Beverages and alcohol. In relation to the rest of the 
World (without EU28 internal trade) Czech agrarian trade is competitive in relation to these commodity groups: Live animals, Dairy products, Sugar, Beverages and alcohol, Oil seeds, Preparation of cereals, Milling products, Cocoa preparations, Vegetable saps and Tobacco products.

The profile of Czech agrarian trade is still not fixed. We can expect significant changes in commodity structure profile and also in its volume and value performance.

Acknowledgements. This paper was supported by Grant Agency of the Faculty of Economics and Management, Czech University of Life Sciences Prague: Analýza komoditní struktury českého agrárního zahraničního obchodu / Analysis of Czech agrarian foreign trade commodity structure [nr. 20171024].

\section{References}

1. Burianová, J., Belova, A.: The competitiveness of agricultural foreign trade commodities of the CR assessed by way of the Lafay Index. Agris On-line Papers in Economics and Informatics 4(4), 27-36 (2012).

2. Burianová, J.: Agrarian foreign trade of the Czech Republic in the period of 2004-2008, competitiveness of commodities. Acta Universitatis Agriculturae et Silviculturae Mendelianae Brunensis 59(4), 37-42 (2011), DOI: 10.11118/actaun201159040037.

3. Burianová, J.: Effect of the 2008-2009 economic crisis on the results of agricultural foreign trade of the Czech Republic. Agricultural Economics 57(5), 226-231 (2011).

4. Clark, J. S., Smutka, L., Čechura, L., Maitah, M., Procházka, P.: The Law of One Price and the Czech Cereal Market Integration into the EU Common Agricultural Market. Ekonomický časopis 63(8), 817-836 (2015).

5. Czech Statistical Office: External Trade Database in cross-border concept, http://apl.czso.cz/pll/stazo/STAZO.STAZO?jazyk=EN, last accessed 2017/10/10.

6. Dalum, B., Laursen, K., Villumsen, G.: Structural change in OECD export specialization patterns: de-specialization and 'stickiness'. International Review of Applied Economics 12(3), 423-443 (1998), DOI: 10.1080/02692179800000017.

7. Fertõ, I.: The evolution of agri-food trade patterns in Central European countries. PostCommunist Economies 20(1), 1-10 (2008), DOI: 10.1080/14631370701865680.

8. Kennedy, P. L., Sonnier, G. P.: Economic integration and international agricultural trade: The case of Central and Eastern Europe. Journal of International Food and Agribusiness Marketing 9(3), 57-72 (1997).

9. Kharcheva, I., Kontsevaya, S., Maitah, M.: Analysis of manpower resources utilization in agricultural organizations of the Russian Federation. In: Auzina, A. (eds.) International Scientific Conference on Economic Science for Rural Development, vol. 42, pp. 244-249. Latvia University of Agriculture, Jelgava (2016).

10. Kontsevaya, S., Alborov, R., Kontsevaya, S.: Estimation of current status of internal economic control in Russian agriculture. In: Auzina, A. (eds.) International Scientific Conference on Economic Science for Rural Development, vol. 43, pp. 290-295. Latvia University of Agriculture, Jelgava (2016).

11. Lafay, G.: The measurement of revealed comparative advantages. In: Dagenais, M. G., Muet, P. A. (eds.) INTERNATIONAL TRADE MODELING, pp. 209-234. Chapman \& Hill, London (1992). 
12. Lukas, Z.: Agricultural reforms in the CEFTA and EU eastern enlargement. MOST: Economic Policy in Transitional Economies 8(2), 143-166 (1998).

13. Pohlová, K., Mezera, J.: Analysis of development of czech foreign trade in foods and beverages. Agris On-line Papers in Economics and Informatics 6(4), 121-131 (2014).

14. Presová, R., Tvrdoň, O., Živělová, A.: Importance of intrastat in EU intra-Community trade. Acta Universitatis Agriculturae et Silviculturae Mendelianae Brunensis 56(3), 175186 (2008), DOI: 10.11118/actaun200856030175.

15. Smutka, L., Špička, J., Ishchukova, N., Selby, R.: Agrarian import ban and its impact on the Russian and European Union agrarian trade performance. Agricultural Economics 62(11), 493-506 (2016), DOI: 10.17221/294/2015-AGRICECON.

16. Smutka, L., Steininger, M., Maitah, M., Škubna, O.: The Czech agrarian foreign trade - ten years after the EU accession. In: 24th International Scientific Conference on Agrarian Perspectives - Global Agribusiness and the Rural Economy, pp. 385-392. CULS Prague, Prague (2015).

17. Svatoš, M.: Selected trends forming European agriculture. Agricultural Economics 54(3), 93-101 (2008).

18. Widodo, T.: Comparative Advantage: Theory, Empirical Measures And Case Studies. Review of Economic and Business Studies (4), 57-82 (2009).

19. Zaghini, A.: Trade advantages and specialization dynamics in acceding countries. Working paper № 249, pp 4-15. European Central Bank, Frankfurt am Main (2003). 